Our Nature (2007)5:41-51

\title{
Phytodiversity in Beeshazar Lake and Surrounding Landscape System
}

\author{
Sasinath Jha \\ Department of Botany, Post Graduate Campus, Tribhuvan University, Biratnagar, Nepal
}

Received: 14.10.2007; Accepted: 26. 10.2007

\begin{abstract}
This paper deals in general with diversity of vascular plants, status of invasive alien species (IAS) and nationally threatened plant species, human use potentials of phytodiversity, and some phytodiversity-based measures to restore and improve the Ramsar characteristics of Beeshazar Lake and surrounding landscape system, which isa part of the Barandabhar forest corridor (BFC) - an extension of buffer zone of the Chitwan National Park, Nepal.
\end{abstract}

Keywords: Phytodiversity, Beeshazar Lake

\section{Introduction}

A Ramsar site spreaded over in 3200 ha area, Beeshazar Lake and the surrounding landscape system (Lat N 2724'-2740', Long E 8421'-8424', average altitude 286 $\mathrm{m}, \mathrm{msl}$ ) is situated within the Barandabhar Forest Corridor (BFC) south to Mahendra Highway in Chitwan district of central Nepal. It is an extension of the buffer zone of Chitwan National Park (a World Heritage Site) supporting an appreciable assemblage of rare, vulnerable and endangered flora and fauna including white-rumped vulture (Gyps bengalensis), Royal Bengal tiger (Panthera tigris), onehorned rhinoceros (Rhinoceros unicornis), Asiatic elephant (Elephas maximus), barking deer, ghariyal (Gavialis gangeticus), smooth-coated otter (Lutra perpiscillata), sloth beer (Melaurus ursinus), marsh crocodile (Crocodylus palustris), lesser adjutant stork (Leptoptilos javanicus), ferruginous duck (Athyra nyroca), band-tailed fish eagle (Haliaetus leucoryphus), and several species of migratory birds. Nevertheless, this unique
Ramsar site is beset with numerous environmental problems, the major ones being its location adjacent to Mahendra Highway, ever increasing human population, high dependence of the majority of local people on the natural resources, and dearth of alternative livelihood options, eutrophication and excessive growth of weeds in the lake, low awareness for conservation benefits, and low incentive for conservation. Maintenance of the lifesupport functions of this Ramsar site requires two basic approaches: (a) scientific study of its varied biodiversity components to develop insights in their ecological functions and human use, and (b) to seek active and informed participation of the local people in landscape management. In this context, the major objective of the present study was to enumerate local as well as invasive, and nationally threatened plant species, along with the frequency of occurrence of each species found in Beeshazar Lake and the surrounding landscapes. 


\section{Materials and Methods}

An intensive survey of the diversity of vascular plants found in Beeshazar Lake and surrounding areas was undertaken in the year 2007. Locations selected for this purpose were Machan area, Beeshazar Lake area, and the Guard Post area of BFC (Figure 1); as well as some homestead orchards occurring in Geetanagar VDC. All the selected locations of BFC possessed diverse habitats including water bodies, marshes/swamps, grasslands and forests even within a radius of $2 \mathrm{~km}$.

The frequency of occurrence of the tree species was estimated using random quadrates of $400 \mathrm{~m}^{2}$ size in adequate numbers. On the average if only one individual occurred per quadrate, the frequency of that tree species was considered occasional; if the number of individuals were between 2 and 4 , the species was categorized as frequent; and those species having 5 or more individuals per $400 \mathrm{~m}^{2}$ area were called abundant. Frequency of occurrence of woody climbers, shrubs, under shrubs, herbaceous climbers, terrestrial herbs, epiphytes, and aquatic herbs was classified into abundant,

The name list of the invasive alien species (IAS) was prepared as per the standard information (Hara et al., 19781982; Jha and Jha, 2000); whereas the list of nationally threatened plant species was prepared as per the information given by Shrestha and Joshi (1996).

Information on human use potentials of the plant species were obtained from the local people and /or through standard literature (CSIR, 1989).

\section{Results and Discussion Phytodiversity}

In total, 507 species of vascular plants (Pteridophytes 17 species; Angiosperms 490 species) were recorded from all the selected locations, among which $14.6 \%$ were trees, $17.6 \%$ shrubs and woody climbers (lianas), $46.6 \%$ terretrial herbs, and $11.4 \%$ aquatic herbs (Jha 2007).

The mixed deciduous forest of the study site was dominated by Shorea robusta (Sal) with Terminalia alata (Asana) as the codominant species. Other major associated tree species were Adina cordifolia (Karma), Alstonia scholaris (Chhatiwan), Cleistocalyx operculatus (Kyamun), Dillenia pentagyna, Duabanga grandiflora (Lampate), Ficus semicordata (Khanyu), Holarrhena pubescens (Madise-khirro), Mallotus philippensis (Sindure), Schleichera oleosa (Kusum), Semecarpus anacardium (Bhalayo), Streblus asper, Syzygium cumini (Jamun), and Toona ciliata (Tooni). Major riverine tree species of the BFC included Acacia catechu (Khair), Bombax ceiba (Simal)), Duabanga grandiflora, Ficus semicordata, Hymenodictyon excelsum (Bhurkul), Terminalia alata, and Trewia nudiflora. The average number of trees in BFC was 270/ha, and average regeneration of trees $890 / \mathrm{ha}$.

Notable shrubs of the BFC were Acacia pennata, Asparagus racemosus (Kurilo), Butea minor (Palas), Caesalpinia bonduc, C. decapetala, Combretum flagrocarpum, Derris cuneifolia, Flacourtia jangomas, Grewia optiva, Justicia adhatoda, Lantana camara, Leea aequata, Mimosa rubicaulis, Phoenix humilis, Woodfordia fruticosa, Xeromphis spinosa and Ziziphus mauritiana; whereas, Abrus precatorius, Ampelocissus latifolia, Bauhinia vahlii (Bhorla), Celastrus paniculatus, Ichnocarpus frutescens, Pothos cathcartii, Scindapsus officinalis, Smilax ovalifolia, Spatholobus parviflorus, and 
Tinospora sinensis were the notable woody climbers (lianas) of the study site.

Among the terrestrial herbs, Chrysopogon aciculatus dominated the heavily grazed grasslands, Imperata cylindrica the moderately grazed grasslands and Saccharum spontaneum was the dominant species in the partially grazed/ungraged grasslands.

Among the hydrophytes of the study site, common emergent species were Acorus calamus, Aeschynomene asper, Brachiaria mutica, Butomopsis latifolia, Ceratopteris thalictroides, Cyperus pilosus, C. platystylis, Echinochloa colona, Hygrophila auriculata, $H$. polysperma, Ipomoea aquatica, I. carnea, subsp. fistulosa, Leersia hexandra, Limnophila heterophylla, Ludwigia adscendens, Marsilea crenata, Monochoria hastata, Oryza rufipogon, Persicaria barbata, $P$. lapathifolia, Sacciolepis indica, Schoenoplectus mucronatus, Sphenoclea zeylanica, Tamarix dioica and Typha angustifolia; common submerged species were Callitriche stagnalis, Ceratophyllum demersum, Hydrilla verticillata, Ottelia alismoides, Potamogeton crispus, Utricularia aurea (an insectivorous plant), and Vallisneria natans; common floating-leafed species were Nymphaea pubescens, Nymphoides hydrophyllum and Trapa quadrispinosa, whereas, notable free-floating species were Azolla imbricata, Eichhornia crassipes, Hygroryza aristata, Lemna perpusilla, Pistia stratiotes, and Spirodela polyrhiza.

In general, there is a shortage of certain nutrients essential for development of life, e.g., minerals such as potassium, calcium, phosphorus and magnesium in the tropical zone; that is why the vegetation present in spite of its abundance, contains a comparatively small amount of these nutrients. Consequently it requires considerable effort from larger animals to collect enough salts to keep their bodies in condition. This explains why only a relatively small density of higher animals is found in the tropical forest. Another reason why these animals need a large area in order to find enough food is that, as a result of there being a larger number of different plant species, only a few individuals of any single species of tree are found, per hectare. Many animals depend on certain trees for their existence and so have to travel great distances. Thus, large tracts of the forest need to be maintained in order to cater for these species.

Grasslands and seasonal marshes of the BFC require management actions to arrest the progressive vegetation succession, and to increase the number and abundance of the palatable herbaceous species for the herbivorous wildlife. It can be achieved either through periodic manual defoliation or through prescribed burning (Riggin et al. 1988). Grazing by domestic livestock is inimical to the interest of wildlife, since wildlife can never compete successfully with domestic stock under ordinary circumstances, and domestic animals transmit contagious diseases to wildlife like foot and mouth disease, rinderpest, surra (sleeping sickness), haemorrhagic septicaemia, anthrax, etc. Keeping animals in stalls and cutting fodder by hand to bring them (zero grazing) can reduce the risk.

\section{Invasive Alien Species (IAS)}

Thirteen invasive alien species (exotic weed species) were recorded from the study area (Table 1) among which the highly obnoxious species were Chromolaena odorata, Eichhornia crassipes, Eupatorium adenophorum, Ipomoea carnea subsp. fistulosa, Lantana camara, Mikania micrantha, and Parthenium hysterophorus. 
S.N. Jha / Our Nature (2007)5: 41-51

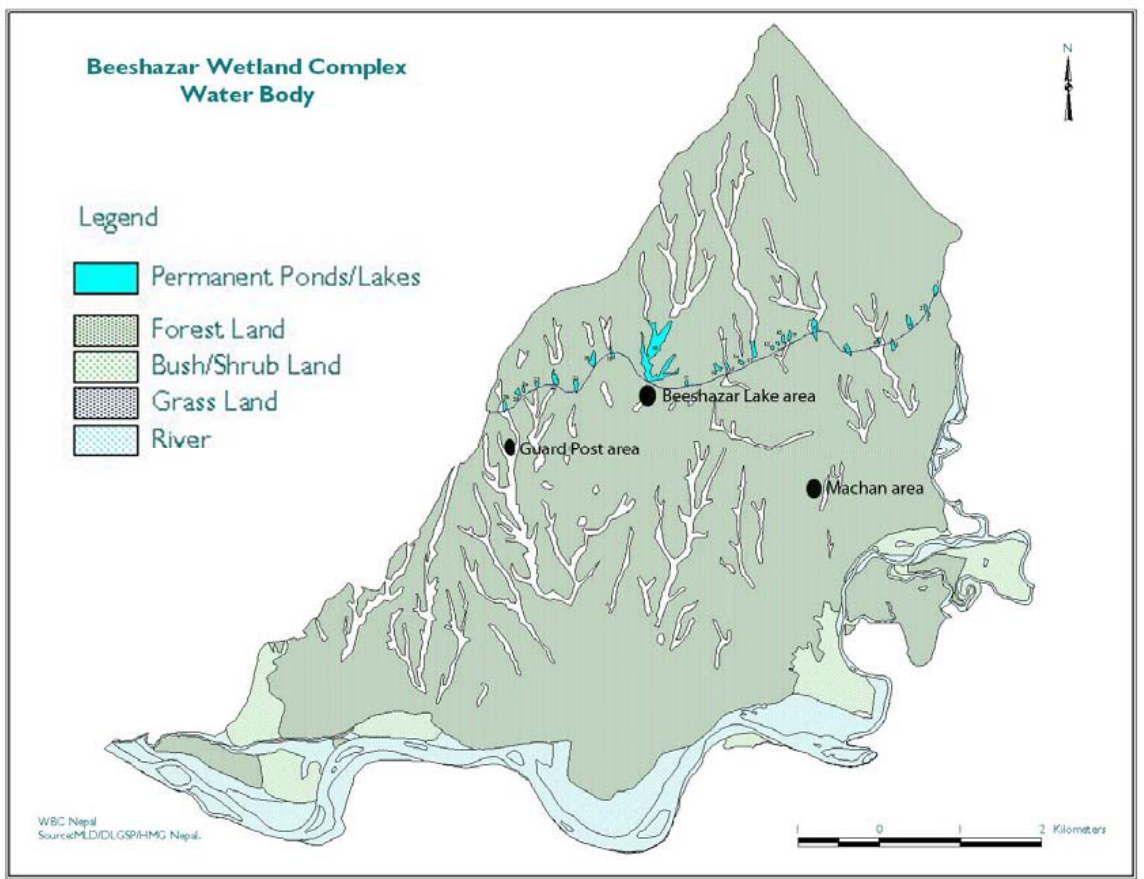

Figure 1. Map of the study site

Table 1. Invasive Alien Species (IAS) of plants (Exotic weed species)

\begin{tabular}{lll}
\hline S.N. & Species & Distribution \\
\hline 1. & Chromolaena odorata & A native of New World Tropics; naturalized \\
2. & Eichhornia crassipes & South America; naturalized widely in Asiatic Tropics \\
3. & Eupatorium adenophorum & A native of Mexico; introduced into the Himalayas about 100 years ago \\
4. & Gomphrena celosioides & Introduced from tropical America; naturalized \\
5. & Hyptis suaveolens & Introduced from tropical America; naturalized \\
6. & Ipomoea carnea subsp. fistulosa & A native of New World Tropics; naturalized \\
7. & Latana camara & Introduced from tropical America; naturalized \\
8. & Mecardonia procumbens & A native of subtropical America; naturalized \\
9. & Mikania micrantha & A native of South America; naturalized \\
10. & Parthenium hysterophorus & A native of tropical America; naturalized \\
11. & Peperomia pellucida & A native of tropical America; naturalized \\
12. & Solanum aculeatissimum & A native of tropical America; naturalized \\
13. & Tridax procumbens & A native of South America; naturalized \\
\hline
\end{tabular}


These species compete with native flora for the resources very successfully, and possess strong allelopatic potentials. Evidences indicate that secretions of pollen grains of the IAS on the stigma can affect the development of pollen or ovule maturation of the native floras (Kanchan and Jayachandra 1980). Thus the IAS are potent threats to native species propagating through seeds. Nevertheless, the allelopathic potential of one IAS can be used in biocontrol of another IAS. For example, Saxena (1992) has reported that aqueous extract of flowers of Lantana camara inhibits the growth of Eichhornia crassipes even at a very low concentration. This biocontrol potential of Lantana camara against Eichhornia crassipes needs intensive investigation in context to the weed problems of Beeshazar Lake.

\section{Nationally threatened plant species}

Among the nationally threatened plant species (Table 2) recorded from the BSF, only Shorea robusta had fairly frequent presence; other species were occasional to scarce in distribution in the study area.

Table 2. Nationally threatened plant species found in Beeshazar lake system and adjoining terrains.

\begin{tabular}{lll}
\hline S.N. & Species & $\begin{array}{l}\text { Frequency of } \\
\text { occurrence }\end{array}$ \\
\hline 1. & Acacia catechu & Occasional \\
2. & Alstonia scholaris & Occasional \\
3. & Asparagus racemosus & Occasional \\
4. & Bombax ceiba & Scarce \\
5. & Oberonia falconeri & Occasional \\
6. & Rauvolfia serpentina & Scarce \\
7. & Piper longum & Scarce \\
8. & Shorea robusta & Frequent \\
9. & Terminalia bellirica & Occasional \\
10. & T. chebula & Scarce \\
11. & Vanda cristata & Occasional \\
\hline
\end{tabular}

\section{Bird habitat}

Birds are the keystone species of the Ramsar site, hence restoration of Beeshazar Lake and adjoining areas must be aimed for the enhancement of protected habitats and improvement of populations of at least huntable water- fowls (ducks, geese and swans) and vanishing wading birds (webless long- legged water birds such as cranes, herons, egrets, etc.). These species depend on the wetlands for food from fish and aquatic insects to plants and their nectar or fruits. Cover and nesting opportunities are also abundant in wetlands due to their natural phytodiversity and general inhospitality to humans; and open water areas provide a barrier to many mammalian predators. Besides these, wetlands reduce temperature extremes through all seasons; their vegetation density provides protective shelter from severe winter winds and summer heat; and tall trees ( living or dead) present within or in the immediate vicinity of the wetlands are the excellent perching and nesting options for several bird species.

In general, for the restoration and enhancement of its Ramsar characteristics Beeshazar lake urgently requires: (i) removal of Eichhornia crassipes and other weeds to maintain clean open water, (ii) introduction of some suitable hydrophytes such as Nelumbo nucifera (Kamal), Nymphaea stellata (red Kumudini), and Nymphoides indica into its shallow-water regions as feed for birds and for their aesthetic aspects; and (iii) plantation of the native pant species such as Acorus calamus (Bojho), Calamus tenuis (Baint), Duabanga grandiflora (Lampate), Erianthus ravennae, Ficus semicordata (Khanyu), Hymenodictyon excelsum (Bhurkul), Narenga porphyrocoma (Kharahi), Pandanus nepalensis (Kebra), Salix tetrasperma, Trewia nudiflora (Guler); and 
Typha angustifolia (Pater) on its land-water interface to check the eutrophication of the lake.

\section{Human use potentials of plant diversity}

People living in the surrounding areas of BSF are primarily agriculture based and horizontal expansion of agriculture has already encroached substantial part of BSF in the past. Solution to this problem is the development and growth of other sectors so that population is weaned away from the land. In this context, plant diversity of BSF has tremendous potentials to be utilized for he establishment of small scale cottage industries such as collection and processing of medicinal plants, 'katha" (catechu), honey, silk, lac, etc; and handicrafts based on traditional skills such as wood-works, weaving of cordage, mats, baskets, etc, (Table 3). It will generate adequate income and employment opportunity for the havenots besides improving the biological environment. It will also encourage social fencing of the BSF. A brief description of the potential uses of the plant diversity of $\mathrm{BSF}$ is given in following paragraphs.

Edible plants: The plants with edible parts are fruits of Bel, Anta, Sarifa, Kathar, Mewa, Aamp, Amba, Aru, Anar, Jamun, Singhara, and Ber. Leaves of Mitho-Neem are used for flavouring curry, whereas fruits of Pate-amla, Amala, Amari, Karona, Imali are used in chutneys and/or in pickles. Young shoots of Podo-sag, Karkalo, Karmi, Purbeli-sag, Sisnu, Nigro, Jibre-sag, Paniand Rukh-neuro are used as pot- herbs.

Feed for livestock: Foliage of 76 plant species were recorded as fodder for livestock out of which notable tree and shrub species were Khair, Chieuri, Kadam,
Kathar, Koiralo, Gayo, Palas, Lampate, Phaledo, Nebharo, Khasreto, Khanyu, Phalsa, Madishe-Khirro, Znmar, Ipil-ipil, Kutmero, Bakaino, Tatelo, Tooni, etc. The foliage of plant species with potentials to increase flow of milk when fed to cattle are Palas, Apang-ghans, Lajjabati, Karmi and Nymphoides hydrophyllum.

Medicinal: Among the enlisted plants with medicinal properties (51 species, Table 3 ): seeds of Abutilon indicum are rich in mucilage and are laxative and demulcent; the powdered rhizomes of Bojho produce beneficial results in cases of dyspesia and chronic diarrhoea; the unripe or half- ripe Belt fruit is regarded as astringent, digestive and stomachic, beneficial in cases of diarrhoea and dysentery; whereas ripe Bel fruit is sweet, aromatic and cooling; the leaves of Gandhe are used for cuts and sores; Gurjo is used as a substitute for Chirayita (Swertia chirayita); Biophytum sensitivum has insulin like principles; fruits of Gaj-pipal and root-barks of Kurilo have aphrodisiac properties; whereas barks of Chhatiwan have abortifacient properties; the fresh tender leaves of Gayo are used for the treatment of jaundice; a concentrated infusion of the roots of Bhimsen-pati finds use as a treatment for malaria; the leaves and seeds of Gainde-kanda are used in external applications for dispersing inflammatory swellings; the fresh juice of Ankuri- phul is prescribed in insaniy, epilepsy and nervous debility; Ghod-tapde is used as diuretic, alterative and tonic, and sometines used in the treatment of leprosy; the seeds of Chrozophora rottleri are used as cathartic; like Ghod- tapde, Commelina benghalensis is also useful in leprosy; the fruits of Aule-bohari is astringent, anthelmintic, diuretic, demulcent and 


\section{S.N. Jha / Our Nature (2007)5: 41-51}

Table 3. Human use of plant species found in Beeshazar Lake system and adjoining areas (Nepali name of the plant species is given in bracket)

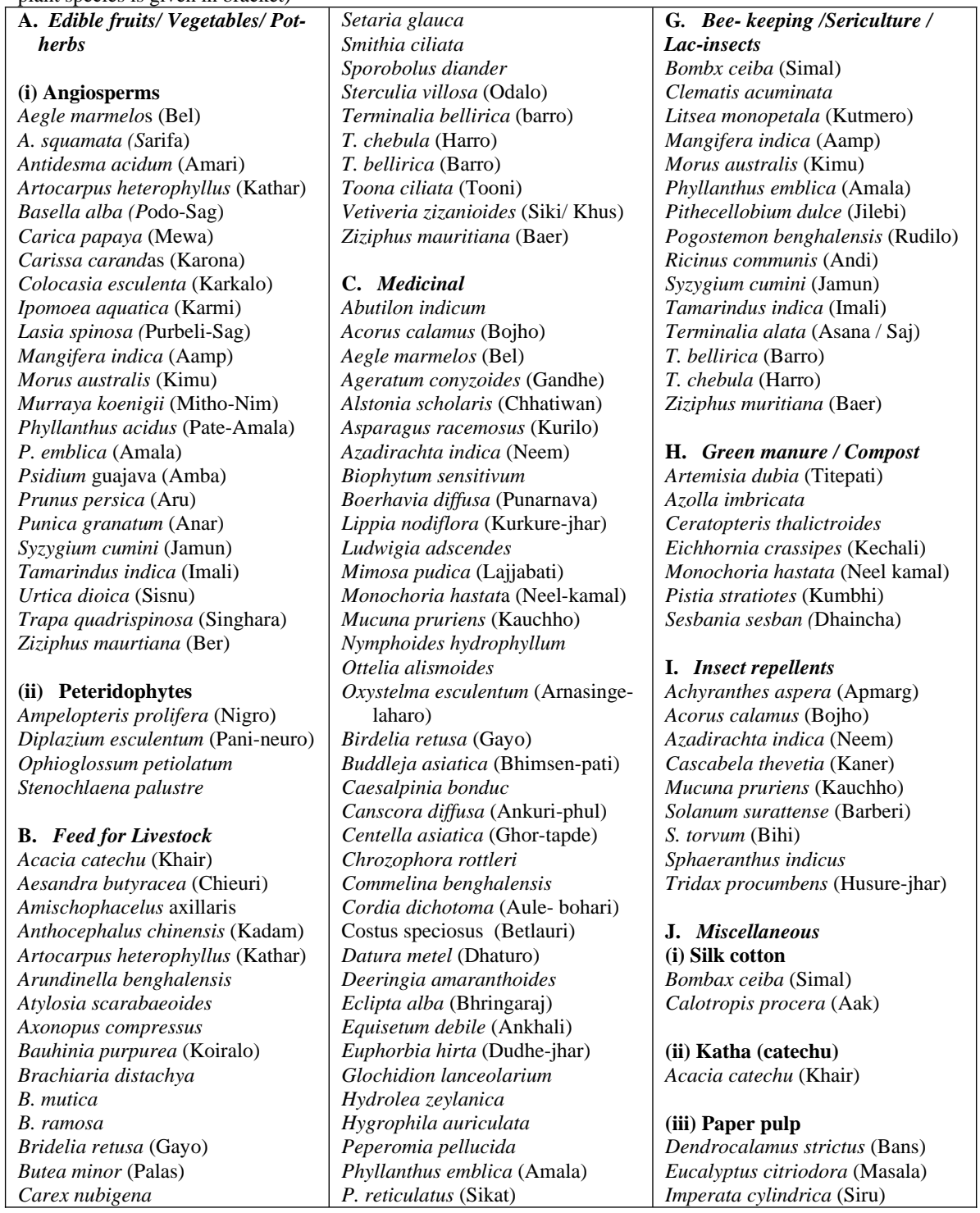

Contd... 
S.N. Jha / Our Nature (2007)5: 41-51

\begin{tabular}{|c|c|c|}
\hline Chrozophora rottleri & Piper longum (Pipla) & Saccharum spontaneum (Kans) \\
\hline Codariocalyx gyroides & Rauvolfia serpentina (Sarpgandha) & \\
\hline Coix lachryma - jobi (Bhirkaule) & Rorippa nasturtium-aquaticum & (iv) Biodiesel /lubricant / edible \\
\hline Commelina benghalensis & Sambucus hookeri (Galeni) & oil \\
\hline C. paludosa & Scindapsus officinalis (Gaj-pipal) & Aesandra butyracea (Chieuri) \\
\hline Cynodon dactylon (Dubo) & Solanum aculeatissimum ( Kataiya) & Jatropha curcas (Baghandi) \\
\hline Dactyloctenium aegypticum & Sphaeranthus indicus & Ricinus communis (castor) \\
\hline Desmodium heterocarpon & Syzygium cumini (Jamum) & \\
\hline D. triflorum (Jungli-Methi) & Terminalia bellirica (Barro) & (v) Breeding stocks \\
\hline Desmostachya bipinnata (Kush) & T. chebula (Harro) & Curcuma zedoaria \\
\hline Dichanthium annulatum & Tinospora sinensis (Gurjo) & Hygroryza aristata \\
\hline Digitaria ciliaris (Chitre-banso) & Tridax procumbens (Hussure-jhar) & Leersia hexandra (Nabo-dhan) \\
\hline Duabanga grandiflora (Lam-pate) & Vallisneria natans & Oryza rufipogon (Jungali-dhan) \\
\hline Echinochloa colona (Sama) & Vetiveria zizanioides (Siki / Khus) & Saccharum spontaneum (Kans) \\
\hline Eleusine indica (Kode-jhar) & & Shuteria involucrata (Bhatmas) \\
\hline Eragrostis tenella & D. Agriculture/hou & Solanum surattense (Barberi) \\
\hline E. unioloides & impleme & S. torvum (Bihi) \\
\hline Erythrina suberosa (Phaledo) & Acacia catechu (Khair) & \\
\hline Ficus auriculata (Nebharo) & Adina cordifolia $(\mathrm{Ka}$ & (vi)Intoxicant / alcoholic drink \\
\hline F. hispida $(\mathrm{Kh}$ & Artocarpus heteroph & Aegle marmelos $(\mathrm{Bel})$ \\
\hline F. semicordat & Bombax ceiba $(\mathrm{Si}$ & Artocarpus heterophyllus (Kathar) \\
\hline Grewia optiva (Phalsa) & Cassia fistula (An & Cannabis sativa (Bhang) \\
\hline Heteropogon contortus & Cassine glauca (Pitojhia) & Ziziphus mauritiana (Baer) \\
\hline Holarrhena & Cordia dichotoma ( & \\
\hline $\mathrm{ca}$ (Siru) & Dalbergia & (vii) Hedge $p$ \\
\hline Indig & Dendrocala & Bauhinia pu \\
\hline (Karmi) & Duabanga & Caesalpinia pulcher \\
\hline Lann & Holarrhen & Deloni \\
\hline Lee & Mitr & Erythrina sub \\
\hline Leuc & Schleiche & Euphorbia pulc \\
\hline Litse & Semecarp & Ficus auriculat \\
\hline folia & Shorea rol & Leucaena leucoc \\
\hline Medicago lupulina & Syzygium & Morus \\
\hline Melia azedirach (Baka & T. bellirica & Murraya koenigii (Mitho-Nim) \\
\hline Mimosa pudica (Lajjabati) & Terminalia alata ( Asana / Saj) & M. paniculata (Kamini) \\
\hline Morus australis (Kimu) & T. chebula (Harro) & Saraca asoka (Asok) \\
\hline Mucuna pruriens (Kauchho) & & Sesbania grandiflora (Agasti) \\
\hline Nymphoides hydrophyllum & E. Thatc & Streblus asper (Sahaur) \\
\hline Oroxylum indicum (Tatelo) & Desmostachya bipinnata (Kush) & Terminalia catappa (Badam) \\
\hline Oryza rufipogon (Jungli-dha & Erianthus ravennae & \\
\hline Panicum paludosum & Imperata cylindrica (Siru) & (viii) Religic \\
\hline Paspalidium flavidum & Narenga porphyrocoma (Kharahi) & Aegle marmelos (Bel) \\
\hline Paspalum conjugatum & Phragmites karka (Narkat) & Cynodon dactylon (Dubo) \\
\hline P. distichum & Saccharum spontaneum (Kans) & Desmostachya bipinnata (Kush) \\
\hline P. scrobiculatum & Typha angustifolia (Pater) & Ficus benghalensis (Bar) \\
\hline Phragmites australis (Narkat) & & F. religiosa (Peepal) \\
\hline P. karka (Narkat) & F. Mat & Oroxylum indicum (Totalo) \\
\hline Phyllodium pulchellum & Chrysopogon aciculatus (Kuro) & Phyllanthus emblica ( Amala) \\
\hline Pogonatherum crinitum & Dendrocalamus strictus (Bans) & \\
\hline rdtia indica $(\mathrm{Py}$ & Typha angustifolia (Pater) & \\
\hline Saccharum spontaneum & Thysanolaena maxima (A & Bauhinia vahlii (Bhorla) \\
\hline Sacciolepis indica & Vetiveria zizanioides (Khus/ Siki) & Shorea robusta $(\mathrm{Sal})$ \\
\hline
\end{tabular}


rhizome of Betlauri is credited with purgative and tonic properties; dried leaves of Dhaturo have narcotic and antispasmodic properties; leaves of Deeringia amaranthoides are applied to sores, and roots of this plant are useful as sternutatory; Bhrigraj is used as tonic and deobstruent in hepatic and spleen enlargements and skin diseases, and leaf-juice of Bhringaraj boiled with coconut oil is used in anointing the head to render the hair black and luxuriant; latex of Dudhe- jhar is used as application for warts; Ankhali contains silica in therapeutically active form; leaves of Hydrolea zeylanica are considered to possess cleansing and antiseptic properties; roots, leaves and seeds of Gokhur-kanda are used as diuretics, and also employed for jaundice, dropsy, rheumatism, anasaraca, diseases of the urinogenital tract; leaves of Sikat are considered diuretic and cooling; the crushed leaves of Peperomia pellucida are used in the applications for headache and fever, and plant juice is given in abdominal pain; fruits of Amala are acrid, cooling, refrigerant, diuretic and laxative; roots of Sarpagandha has sedative properties; Rorippa nasturtium-aquaticum possesses antiscorbutic and stimulant properties and is eaten fresh to improve appetite; a powder of the leaves of Galeni is used as snuff to stop bleeding of the nose; pounded roots of Kataiya are applied to the gums to relieve toothache; juice of Bhuinkadam is styptic and said to be useful in liver and gastric disorders; extracts of bark and seeds, and also leaves of Jamun are used in the treatment of diabetes; the fruit of Barro is well-known commercial myrobalan called bellric myrobalan; in combination with Amala and Barro, fruits of Harro are extensively used as adjuncts to other medicines in almost all diseases under the name 'Triphala,' leaves of Husure-jhar are reported to be employed for restoring hair; the vetiver oil obtained from the roots of Siki / Khus is applided locally in rheumatism, lumbago and sprain; and Vallisneria natans is used as a stomachic, and for leucrrhoea.

\section{Agricultural and household implements:} Woods of 19 plant species (Table 3) are suitable for the construction of agricultural and household implements including ploughs, yokes, tool handles, carts, cartwheels, spokes, cots, pegs, pestles, pastry board, pastry roller, churner, door frames, furniture, etc.

Thatch and cordage: Plants used for thatching the huts and cattle shedes are Kush, Erianthus ravennae, Siru, Kharahi, Narkat, Kans, and Pater; whereas Kans and barks of Odalo are used in making cordage.

Mats/ brooms/ basketry: Culms of Pater and rachis of Khus are woven into mats; Bans are used for wicker-work, baskets and other types of containers and furniture; and roots of Khus are used in making screens (Khus-chicks) which are hung like curtains in the houses, and when sprinkled with water impart a fragrant coolness to the air. The culms of Amliso and Kuro are used as brooms.

Bee-keeping/ sericulture/ lac-insects: The blossoms of Simal, Clematis acuminata, Aamp, Amala, Jilebi, Rudilo, Jamun, Imali, Harro and Barro are important sources of nectar for the honey-bees; the tasar silkworms (Antheraea mylitta) feed on the foliage of Jamun, Asana, Kimu, Andi and Barro and Muga silkworms feed on the 
foliage of Kumtero; whereas Imali and Baer are the hosts of lac-insects.

Green manure/ compost: The plant species utilized as green manure and compost are Azolla imbricata which harbours Anabaena azollae, a nitrogen fixing blue-green alga (BGA) in its foliar intercellular spaces; whereas Titepati, Pani-dhaniya, Kechali, Neel-kamal, Kumbhi, and Dhaincha can be utilized in compost preparation.

Insect repellents: The powdered rhizome of Bojho possesses insecticidal properties and is useful against bed-bugs, moths, lice, etc.; fruits of Barberi and Bihi contain active principles against mosquito larvae; the petroleum ether axtract of Husure-jhar has insecticidal and parasiticidal properties; dried shoots of Neem and Bhuin-kadam are mixed with paddy and wheat grains to prevent their damage in storage; and, the seeds of Apmarg ground into a paste are used as external application for poisonous insect-bites.

Miscellaneous: (i) Silk cotton: Floss of Simal and Aak is suitable for stuffing mattresses, cushions and pillows; (ii) Katha (catechu); Khair: yields catechu for use in Pan (betel) preparation; (iii) Paper pulp: Plants suitable for paper-plup are Bans, Masala, Siru and Kans; (iv) Biodiesel/ lubricant/ edible oil: Flowers of Chieuri yield edible butter ; seeds of Baghandi yield bio-diesel; and seeds of Andi (castor) yield lubricant used in bullock carts; (v) Breeding stocks: Hygroryza aristata, Nabo-dhan and Jungali- dhan may be used as breeding stocks for paddy; Kans for sugarcane; Barberi for brinjal; Bihi for tomato; Shuteria involucrata for soybean; and Curcuma zedoaria for turmeric; (vi)
Country liquor: Fruits of Bel, Kathar and Baer have potentials to be used in preparation of country liquor, whereas leaves of Bhang is used as a traditional intoxicant; (vii) Food plates: Leaves of Sal and Bhorla are used as food plates; (viii) Hedge plants: Fourteen plant species enlisted in Table 3 are suitable for hedge/ fencing; (ix) Religious plants: Notable religious plants of the study site were Bel, Dubo, Kush, Bar, Peepal, Tatelo and Amala.

\section{Acknowledgements}

Author is thankful to the Society for Wetlands and Biodiversity Conservation Nepal (WBC Nepal) Kathmandu, Nepal for the financial support. Thanks are also due to Sri Yam Bahadur Bam (WBC Nepal), Sri Paras Acharya (Trichandra Campus, Kathmandu), Sri Kedar Dahal (Trichandra Campus, Kathmandu), Sri Hark Man Lama (Chitwan National Park, Chitwan), and Sri Vasu Jee (Sauraha, Chitwan) for their generous and inspiring companionship during the field work.

\section{References}

CSIR (Council of Scientific \&ndustrial Research). 1989. The wealth of India: Raw materials, volumes I - IXNew Delhi.

Hara, H., A.O. Chater and L.H.J. Williams (eds). 1982. An enumeration of the flowering plants of Nepal, volume 3. British Museum (Natural History) publication 854: 1-226. London.

Hara, H., W.T. Stearn and L.H.J. Williams (eds). 1978. An enumeration of the flowering plants of Nepal, volume 1. British Museum (Natural History) publication 777: 1- 154, London.

Hara, H., and L.H.J. Williams (eds). 1979. An enumeration of the flowering plants of Nepal, volume 2. British Museum (Natural History) publication 810: 1- 220.

Jha, S. 2007. Plant diversity found in Barandabhar forest corridor (BFC) including Beeshazar Lake, Chitwan district, Nepal. Report, WBC Nepal. 
S.N. Jha / Our Nature (2007)5: 41-51

Jha, S. and P.K. Jha. 2000. Contributions to the flora of Morang district and adjoining areas of Nepal. Lidia (A Norwegian Journal of Botany) 5(1): 25- 64.

Kanchan, S. and Jayachandra. 1980. Pollen allelopathy a new problem. New Phytologist 84: 739- 746.

Riggin, P.J., S. Goode, P.M. Jacks and R.N. Lockwood. 1988. Interaction of fire and community development in chaparral of south California. Ecological Monographs 58: 155- 176.
Saxena, M. 1992. Allelopathic potential of terrestrial plants against the growth of aquatic weds. In Allelopathy in agroecosystems (Eds. P. Tauro and S.S. Narwal), Indian Society of Allelopathy, Haryana Agricultural University, Hisar. pp.147148.

Shrestha, T.B. and R.M. Joshi 1996. Rare, endemic and endangered plants of Nepal. WWF Nepal, Kathmandu. 